УДК 685.34(045)

T.M.APTЮX

Київський національний університет імені Тараса Шевченка

I.В.ГРИГОРЕНКО, А.С.ТЕРНОВА Вінницький торговельно-економічний інститут КНТЕУ

\title{
ТОВАРОЗНАВЧА ОЦІНКА ЗАСОБІВ ПО ДОГЛЯДУ ЗА ВЗУТТЯМ РІЗНИХ ВИРОБНИКІВ НА РИНКУ УКРАЇНИ
}

T.M.APTЮX

Киевский наииональный университет имени Тараса Шевченко

И.В.ГРИГОРЕНКО, А.С.ТЕРНОВАЯ

Винницкий торгово-экономический институт КНТЭУ

\section{ТОВАРОВЕДНАЯ ОЦЕНКА СПРЕЕВ ПО УХОДУ ЗА ОБУВЬЮ РАЗНЫХ ПРОИЗВОДИТЕЛЕЙ НА РЫНКЕ УКРАИНЫ}

\author{
T.ARTYUKH \\ Kyiv National Taras Shevchenko University \\ I. HRYHORENKO, A.TERNOVA \\ Vinnitsia Trade and Economic Institute of Kyiv National Trade and Economic University

\section{SPECIAL ASSESSMENT OF SPRAYS FOR CARE OF SHOES OF DIFFERENT PRODUCERS ON THE UKRAINE MARKET}

\section{https://doi.org/10.36910/6775-2310-5283-2020-13-08}

Мета. Встановлення класифікаційних показників засобів догляду за взуттям та проведення товарознавчої оцінки спреїв для оновлення кольору.

Методика. Дослідження провадились иляхом застосування загальнонаукових методів, порівняльного та системного аналізів, а також застосовано об'єктивні та суб'єктивні методи: діагностичні та інформаційно-аналітичні (математичні, експертні, логічні тощз).

Результати. У статті представлено аналіз базових класифікаційних показників засобів догляду за взуттям. Проведено аналіз чинних вимог до якості, маркування та пакування об'єкта досліджень. Встановлено, щзо в Україні не має жодного спечіалізованого ДСТУ на засоби догляду за взуттям. Майже всі виробники, щчо представлені на ринку розробляють власті технічні умови, або користуються дотичними нормативними документами. Здійснено товарознавчу оцінку фарб для оновлення кольору вітчизняних та іноземних виробників, щзо представлені на вітчизняному ринку. Запропонований авторами алгоритм товарознавчої оцінки передбачає етапи: дослідження 
відповідності маркування; перевірку стану та якості пакування; оцінку показників функиіональних властивостей; розрахунок комплексного показника якості методом експертних оцінок. Така схема дозволяє підвищити ефективність формування асортименту в роздрібних мережах.

Наукова новизна. Запропоновано класифікаџію засобів по догляду за взуттям за базовими показниками; удосконалено алгоритм товарознавчої оцінки засобів догляду за взуттям, зокрема фарб для оновлення кольору.

Практична значимість. Одержані результати оцінки якості спреїв для взуття та запропонована автором класифікачія можуть використовуватись фахівцями під час формування асортименту засобів по догляду за взуттям в торговельних мережах Украйни.

Ключові слова: засоби по догляду за взуттям, спреї для оновлення кольору, товарознавча оцінка, класифікачія, асортимент.

Постановка проблеми у загальному вигляді та іï зв'язок із важливими науковими чи практичними завданнями. Збереження функціональних та ергономічних властивостей взуття впродовж носіння залежать від його належного догляду. Цей процес розпочинається 3 моменту покупки взуття. Фахівці вважають, що на початку експлуатації взуття необхідно ретельно обробити спеціальними засобами. Незалежно від ретельності і регулярності чищення взуття, з часом взуття частково втрачає ефект просочення. Це природний процес неминуче призводить до зниження якості взуття і зменшення комфортності. Тому оцінювання засобів по догляду за взуттям відповідно до встановлених вимог якості та безпечності, вмісту складових компонентів, що забезпечують високі гігієнічні, функціональні властивості та безпечність впродовж експлуатації $є$ актуальною проблемою сьогодення. Сучасний ринок товарів по догляду за взуттям вражає своїм розмаїттям, однак вітчизняні виробники поступово втрачають на ньому свої позиції: все більше імпортних виробів, нерідко нізького рівня.

У [1] вказано, що засоби по догляду за взуттям входять до групи товарів побутової хімії і $є$ однорідними пастоподібними і вощаноподібними речовинами (креми, гуталіни) або водяні емульсії (апертури).

Їх основне призначення полягає у покращені зовнішнього вигляду взуття, підвищення м'якості, еластичності і водонепроникності шкіри або інших матеріалів, із яких виготовлено взуття. Завдяки цьому верх взуття триваліший час зберігає свої початкові властивості [1]. До складу взуттєвих кремів входять переважно парафін та віск-мантан, у меншій кількості - бджолиний віск, які попередньо сплавляють, а потім розчиняють скипидаром і (або) водою, додають барвники [1]. Вказано, що креми випускають різних кольорів 
i безбарвні. Вони повинні бути однорідними, не липкими, без грудок і зерен із блискучою поверхнею і запахом скипидару (розчинника).

Варто відзначити, що питання якості, безпечності та формування асортименту засобів по догляду за взуттям в науковій літературі не було висвітлено. Таким чином, розгляд основних аспектів товарознавчої оцінки та виявлення споживчих переваг на ринку засобів по догляду за взуттям $\epsilon$ актуальною темою і являє собою великий теоретичний і практичний інтерес.

Аналіз останніх досліджень, у яких започатковано вирішення проблеми. Проблема формування структури торгового та промислового асортименту, оцінка рівня якості та виявлення споживчих переваг засобів по догляду за взуттям складна та багатогранна. Основа інформація про асортимент, властивості, сферу застосування і ціни основних видів засобів по догляду за взуттям міститься в переважній більшості у періодичних виданнях компаній і фірм-виробників; рекламних проспектах вітчизняних і зарубіжних підприємств, які займаються виробництвом і збутом взуттєвої косметики; окремих каталогах i рекламних проспектах спеціалізованих магазинів, супермаркетів, Інтернет-магазинів тощо.

Аналіз інформації про асортимент і властивості засобів по догляду за взуттям, вказує на те, що ця інформація носить тільки рекламний характер виробників і є неповною і недостатньою для об'єктивної товарознавчої оцінки цих товарів. 3 цієї інформації практично не можливо здійснити характеристику засобів по догляду за взуттям аналогічного призначення, зокрема визначити переваги і недоліки аналогічних виробів; визначити вплив окремих компонентів складу на споживні властивості, показники якості та безпечність. Відсутні і грунтовні наукові дослідження якості та безпечності засобів по догляду за взуттям.

Так, можна стверджувати, що проблематика якості та безпечності засобів по догляду за взуттям в наукових виданнях не розкрита.

Цілі статті. Оцінка споживних властивостей, якості та класифікаційних ознак засобів по догляду за взуттям на ринку України.

Виконання роботи базується на основі вирішення наступних завдань:

- визначення класифікаційних ознак сучасного асортименту засобів по догляду за взуттям;

- встановлення вимог до якості та маркування засобів по догляду за взуттям;

- товарознавча оцінка засобів по догляду за взуттям, що реалізується у торговельній мережі України. 
Об’єкт дослідження. Засоби по догляду за взуттям представлені до реалізації на ринку України.

Методи дослідження. Для проведення теоретичних досліджень застосовано загальнонаукові методи, методологія порівняльного та системного аналізів. Експериментальні дослідження проводились за допомогою об'єктивних та суб'єктивних методів, зокрема, лабораторних та інформаційно-аналітичних. Показники функціональних властивостей фарб для оновлення кольору визначали стандартними методами за показниками: швидкості висихання в хвилинах, покривності, насиченості кольору, стійкості до стирання, липкості та здатності до відштовхування краплин води [2 - 4].

Виклад основного матеріалу дослідження 3 повним обгрунтуванням отриманих наукових результатів. Косметика для взуття - це засоби, призначені для поліпшення зовнішнього вигляду шкіряного або текстильного взуття, продовження його терміну служби, збереження показників споживних властивостей та їх характеристик. Інші поширені назви такої групи товарів «засоби по догляду за взуттям» і «взуттєва косметика» [1].

Товари по догляду за взуттям поділяються на групи [5]: аксесуари для взуття, засоби по догляду за взуттям, устілки для взуття.

Згідно з УКТЗЕД, Розділ VI (28-38) класифікація продукції хімічної та пов'язаних 3 нею галузей промисловості, що використовуються по догляду за взуттям представлена в таблиці 1.

Таблиця 1

\section{Класифікація продукції хімічної та пов'язаних з нею галузей} промисловості, що використовуються по догляду за взуттям згідно 3 УКТЗЕД, Розділ VI (28-38) [5]

\begin{tabular}{|c|c|}
\hline Група 34 & $\begin{array}{l}\text { Мило, поверхнево-активні органічні речовини, мийні засоби, мастильні } \\
\text { матеріали, воски штучні та готові, суміші для чищення або полірування, } \\
\text { свічки та аналогічні вироби, пасти для ліплення, пластилін, } \\
\text { «стоматологічний віск» і суміші на основі гіпсу для стоматології }\end{array}$ \\
\hline 3405 & $\begin{array}{l}\text { Вакси та креми для чищення взуття, мастики, полірувальні засоби для } \\
\text { догляду за меблями, підлогою, кузовами транспортних засобів, склом або } \\
\text { металом, пасти для чищення, порошки та аналогічні засоби (у тому числі } \\
\text { папір, вата, повсть, фетр, неткані матеріали, пластмаси або гума пориста, } \\
\text { просочені або вкриті цими речовинами), за винятком восків товарної позиції } \\
\text { 3404: }\end{array}$ \\
\hline 34053000 & $\begin{array}{l}\text { полірувальні засоби та аналогічні засоби для догляду за кузовами } \\
\text { транспортних засобів, крім полірувальних засобів для металів }\end{array}$ \\
\hline 3405300010 & $\begin{array}{l}\text { що використовуються для промислового складання моторних транспортни } \\
\text { засобів }\end{array}$ \\
\hline & \\
\hline
\end{tabular}


Засоби по догляду за взуттям класифікується відповідно до матеріалу, 3 якого виготовлено взуття: для шкіри, лакованої шкіри, нубуку, замші, текстилю.

Догляд за взуттям передбачає безліч процедур: від миття до покриття спеціальними рідинами або кремами. Асортимент засобів по догляду за взуттям за призначенням можна класифікувати так: косметика для очищення, косметика для насичення і полірування, водовідштовхувальна косметика, косметика для фарбування.

Класифікація засобів по догляду за взуттям за видами, що використовуються при формуванні асортименту торговельними підприємствами наведена на рис. 1 .

Аерозолі спреї для догляду за замшем, текстилем, шкірою, велюру, набуком

Дезодоранти для взуття

Засоби для прання мембрани, мікроволокон, пуху

Креми для взуття

Льодоступи

Водовідштовхуючі засоби

Щітки для взуття

Рис. 1. Класифікація засобів по догляду за взуттям за видами

Засоби по догляду за взуттям не підлягають обов'язковій сертифікації, тому виробник або продавець має можливість самостійно обрати ті характеристики своєї продукції, які він хоче підтвердити (безпечність, якість товару) та отримати сертифікат або декларацію відповідності. Вироблення декларації або сертифікату відповідності здійснюється на підставі нормативного або технічного документу, відповідно до якого виготовлено продукцію.

В Україні не має жодного спеціалізованого ДСТУ на засоби по догляду за взуттям. Майже всі виробники, що представлені на ринку розробляють власті технічні умови або користуються дотичними нормативними документами. 
Так, вимоги ТУ 6-15-984-86 «Засоби рідкі по догляду за взуттям та виробами зі шкіри» поширюються на рідкі емульсійні засоби, що представляють забарвлену або незабарвлену дисперсію натуральних i синтетичних восків, парафіну, церезину, органічних розчинників, води i корисних добавок [6]. Відповідно до технічного документу сировина, що застосовується повинна відповідати вимогам якості, зазначеної в рецептурах.

Фізико-хімічні показники та показники якості для засобів рідких по догляду за взуттям та виробами зі шкіри зазначені в таблиці 2.

Таблиця 2

Характеристика фізико-хімічних показників, показників якості засобів

по догляду за взуттям

\begin{tabular}{|l|c|}
\hline \multicolumn{1}{|c|}{ Найменування показника } & \multicolumn{1}{|c|}{ Значення показника } \\
\hline Зовнішній вигляд, колір і запах & $\begin{array}{c}\text { Рідка або напіврідка дисперсія, відповідного } \\
\text { кольору, зі слабким запахом розчинника. При } \\
\text { стоянні допускається розшарування, що зникає } \\
\text { при струшуванні і не впливає на якість }\end{array}$ \\
\hline $\begin{array}{l}\text { Масова частка нелетких } \\
\text { речовин,\%, }\end{array}$ & \multicolumn{1}{|c|}{ не менше 12 } \\
\hline $\begin{array}{l}\text { Показник концентрації водневих } \\
\text { іонів (рН) водної витяжки, рН }\end{array}$ & $12-14$ \\
\hline $\begin{array}{l}\text { Блиск плівки, од. шкали } \\
\text { блискоміра, не менше }\end{array}$ & $0,7-0,8$ \\
\hline $\begin{array}{l}\text { Пиленакопичення плівки, мг/см² } \\
\text { не більше }\end{array}$ & 80 \\
\hline Водостійкість плівки, бали & \multicolumn{1}{|c|}{} \\
\hline
\end{tabular}

Відповідно до ТУ, засоби повинні відповідати вимогам, бути виготовлені за рецептурою $\mathrm{i}$ технологічною документацією, затвердженими в установленому порядку [7, 8]. Фізико-хімічні показники, що забезпечують якість та безпечність засобів, наведені в таблиці 3.

Термін придатності та гарантійний термін зберігання (для засобів 3 необмеженим терміном придатності) вказані в технічній документації на засоби.

Не допускається використання в якості пропеленту озоноруйнуючих хладонів. Приймання продукції у роздрібній мережі відбувається відповідно до СОУ МПП 71.100-077:2004 [9], процес транспортування та зберігання засобів по догляду за взуттям регламентується СОУ МПП 71.100-078:2004 [10]. 
Таблиця 3

Фізико-хімічні показники засобів по догляду за взуттям

\begin{tabular}{|c|c|}
\hline Найменування показника & Значення показника \\
\hline $\begin{array}{l}\text { Міцність і герметичність аерозольної } \\
\text { упаковки }\end{array}$ & повинна витримувати випробування \\
\hline $\begin{array}{l}\text { Працездатність клапана аерозольної } \\
\text { упаковки }\end{array}$ & повинен витримувати випробування \\
\hline $\begin{array}{l}\text { Надмірний тиск в аерозольній упаковці при } \\
20^{\circ} \mathrm{C} \text {, МПа (кгс): } \\
\text { для засобів з використанням в якості } \\
\text { пропеленту зріджених газів і вуглекислого } \\
\text { газу } \\
\text { для засобів з використанням в якості } \\
\text { пропеленту стислих газів }\end{array}$ & $\begin{array}{l}0,20(2,0)-0,60(6,0) \\
0,55(5,5)-0,90(9,0)\end{array}$ \\
\hline $\begin{array}{l}\text { Масова частка пропеленту,\% } \\
\text { (*Для засобів, що містять в якості } \\
\text { пропеленту вуглекислий газ або стиснене } \\
\text { повітря, показник не визначають) }\end{array}$ & $\begin{array}{c}\text { Повинна відповідати встановленої в } \\
\text { технічній документації на засіб }\end{array}$ \\
\hline $\begin{array}{l}\text { Ступінь евакуації вмісту аерозольної } \\
\text { упаковки, } \%, \text { не менше }\end{array}$ & 95 \\
\hline
\end{tabular}

Об’єктами товарознавчої оцінки було обрано п’ять зразків фарб для оновлення чорного кольору взуття виготовленого із ворсових матеріалів різних виробників, упакованих в аерозольний балон (пропелент) 3 тридетальної білої жерсті, номінального об'єму 300 мл.. На кожній упаковці вказано товарний знак виробника, рекомендації щодо способу застосування, відомості про застережні заходи, відомості про вогненебезпечність, дата виготовлення, штрих-код, інформація щодо умов акції. Спосіб нанесення маркування: офсетний друк на жерсть або полімерну плівку. Видимих дефектів ковпачка та балону не виявлено.

Результати досліджень маркування обраних зразків наведені в таблиці 4.

Встановлено, що зразки 1 (TM Salton), 4 (TM Twist) та 5 (TM Blyskavka) повністю відповідають вимогам [7] в частині споживчого маркування. У зразках 2 (TM Silver) та 3 (TM Sitil) відсутні відомості щодо нормативного документу, за яким виготовляється товар. У зразках 3 (TM Sitil) та 5 (ТМ Blyskavka) не вказана маса нетто продукту. Хімічний склад із зазначенням відсоткового діапазону сполук наведено лише зразках 2 (TM Silver) та 4 (TM Twist). Водночас відсутність у складі досліджуваних зразків силікону $є$ опосередкованим підтвердженням відповідної якості усіх обраних фарб для взуття. 
Таблиця 4

Характеристика ознак маркування фарб для оновлення чорного кольору різних виробників

\begin{tabular}{|c|c|c|c|c|c|}
\hline \multirow{3}{*}{$\begin{array}{l}\text { Наймену- } \\
\text { вання } \\
\text { показника }\end{array}$} & \multicolumn{5}{|c|}{ Торговельна марка } \\
\hline & Salton & Silver & Sitil & Twist & Blyskavka \\
\hline & Зразок 1 & Зразок 2 & Зразок 3 & Зразок 4 & Зразок 5 \\
\hline 1 & 2 & 3 & 4 & 5 & 6 \\
\hline $\begin{array}{c}\text { Назва } \\
\text { продукту }\end{array}$ & $\begin{array}{c}\text { Salton } \\
\text { краска } \\
\text { для } \\
\text { замши и } \\
\text { нубука } \\
\end{array}$ & $\begin{array}{c}\text { Спрей } \\
\text { Краска- } \\
\text { востановитель } \\
\text { для нубука и } \\
\text { замши } \\
\end{array}$ & $\begin{array}{c}\text { Краска- } \\
\text { аэрозоль для } \\
\text { замши и } \\
\text { нубука }\end{array}$ & $\begin{array}{c}\text { Краска для } \\
\text { замши, велюра, } \\
\text { нубка }\end{array}$ & $\begin{array}{c}\text { Фарба для } \\
\text { замші, } \\
\text { велюру та } \\
\text { нубуку }\end{array}$ \\
\hline 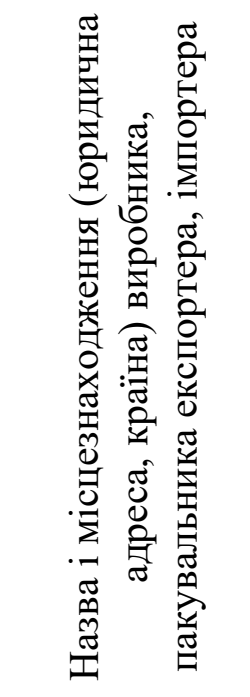 & 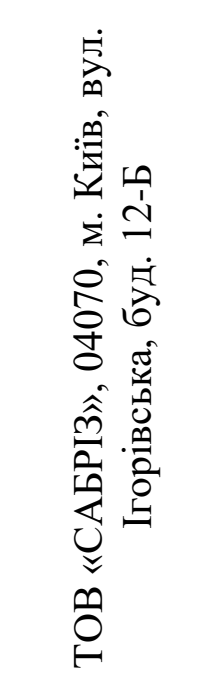 & 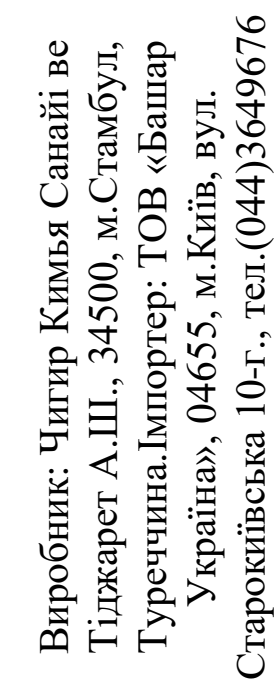 & 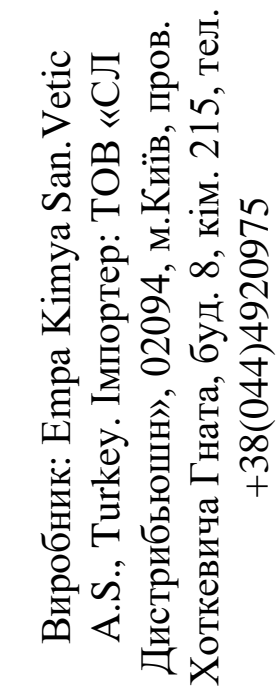 & 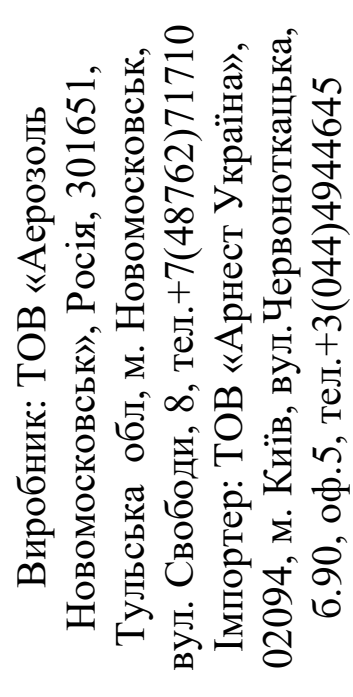 & 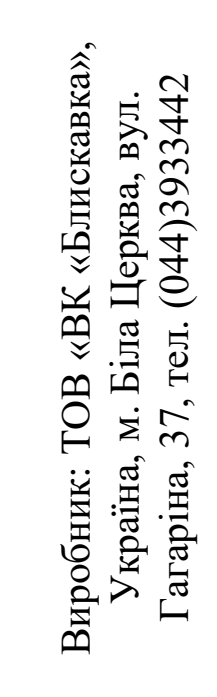 \\
\hline $\begin{array}{c}\text { Додатковий } \\
\text { ефект }\end{array}$ & $\begin{array}{l}\text { Зберігає } \\
\text { первісну } \\
\text { ворсисту } \\
\text { структуру } \\
\text { матеріалів }\end{array}$ & $\begin{array}{c}\text { Водовідштовх } \\
\text { увальний } \\
\text { ефект }\end{array}$ & $\begin{array}{c}\text { Зберігається } \\
\text { бархатиста } \\
\text { структура } \\
\text { матеріалу. } \\
\text { Водовідштовх } \\
\text { увальний } \\
\text { ефект }\end{array}$ & $\begin{array}{c}\text { Захищає від } \\
\text { вологи, снігу, } \\
\text { солей }\end{array}$ & $\begin{array}{l}\text { Захищає } \\
\text { від } \\
\text { сонячних } \\
\text { променів }\end{array}$ \\
\hline Маса нетто, Г & 210 & 210 & Не вказано & 217 & Не вказано \\
\hline $\begin{array}{l}\text { Озоно- } \\
\text { руйнівні } \\
\text { хладони }\end{array}$ & $\begin{array}{l}\text { Вказано, } \\
\text { що не } \\
\text { містись } \\
\text { (текст, } \\
\text { знак) } \\
\end{array}$ & $\begin{array}{c}\text { Вказано, що } \\
\text { не містись } \\
\text { (знак) }\end{array}$ & $\begin{array}{c}\text { Вказано, що } \\
\text { не містись } \\
\text { (знак) }\end{array}$ & $\begin{array}{c}\text { Вказано, що не } \\
\text { містись } \\
\text { (текст, знак) }\end{array}$ & $\begin{array}{c}\text { Не } \\
\text { зазначено }\end{array}$ \\
\hline $\begin{array}{l}\text { Озоно- } \\
\text { руйнівні } \\
\text { хладони }\end{array}$ & $\begin{array}{c}\text { Вказано, } \\
\text { що не } \\
\text { містись } \\
\text { (текст, } \\
\text { знак) }\end{array}$ & $\begin{array}{c}\text { Вказано, що } \\
\text { не містись } \\
\text { (знак) }\end{array}$ & $\begin{array}{c}\text { Вказано, що } \\
\text { не містись } \\
\text { (знак) }\end{array}$ & $\begin{array}{c}\text { Вказано, що не } \\
\text { містись } \\
\text { (текст, знак) }\end{array}$ & $\begin{array}{c}\text { Не } \\
\text { зазначено }\end{array}$ \\
\hline
\end{tabular}




\begin{tabular}{|c|c|c|c|c|c|}
\hline 1 & 2 & 3 & 4 & 5 & 6 \\
\hline Склад & $\begin{array}{c}\text { Синте- } \\
\text { тичні } \\
\text { смоли, } \\
\text { суміш } \\
\text { органіч- } \\
\text { них } \\
\text { розчин- } \\
\text { ників, } \\
\text { барвники, } \\
\text { пропан, } \\
\text { бутан }\end{array}$ & $\begin{array}{c}\leq 5 \% \text { : барвник, } \\
\text { фторкарбо- } \\
\text { нова смола; } \\
\text { >30\%: } \\
\text { розчинники, } \\
\text { пропан/бутан }\end{array}$ & $\begin{array}{l}\text { Ізопропілен, } \\
\text { барвник, } \\
\text { віддушка, } \\
\text { бутан, пропан }\end{array}$ & $\begin{array}{c}<5 \%: \text { комплекс } \\
\text { Голд Амбер, } \\
\text { фторкарбонова } \\
\text { смола, віддушка; } \\
\geq 5 \% \text { але }<15 \% \text { : } \\
\text { фарбники, бутил- } \\
\text { ацетат, метиловий } \\
\text { ефір діпропі- } \\
\text { ленгліколю, } \\
\text { етилацетат; } \geq 15 \% \\
\text { але <30\% - спирт } \\
\text { ізоприлови; } \geq 30 \%: \\
\text { аліфатичні } \\
\text { вуглеводні } \\
\text { (пропан, бутан, } \\
\text { ізобутан) } \\
\end{array}$ & $\begin{array}{c}\text { Пропан/ } \\
\text { бутан, } \\
\text { ізопропан- } \\
\text { ол, } \\
\text { барвник, } \\
\text { водовідшт } \\
\text { овхуваль- } \\
\text { на диспер- } \\
\text { сійна } \\
\text { речовина, } \\
\text { консер- } \\
\text { вант, вода, } \\
\text { віддушка }\end{array}$ \\
\hline $\begin{array}{l}\text { Озоно- } \\
\text { руйнівні } \\
\text { хладони }\end{array}$ & $\begin{array}{c}\text { Вказано, } \\
\text { що не } \\
\text { містись } \\
\text { (текст, } \\
\text { знак) } \\
\end{array}$ & $\begin{array}{c}\text { Вказано, що } \\
\text { не містись } \\
\text { (знак) }\end{array}$ & $\begin{array}{c}\text { Вказано, що } \\
\text { не містись } \\
\text { (знак) }\end{array}$ & $\begin{array}{c}\text { Вказано, що не } \\
\text { містись } \\
\text { (текст, знак) }\end{array}$ & $\begin{array}{c}\text { Не } \\
\text { зазначено }\end{array}$ \\
\hline $\begin{array}{c}\text { Умови } \\
\text { зберігання }\end{array}$ & $\begin{array}{l}\text { від } 0{ }^{\circ} \mathrm{C} \\
\text { до } 35^{\circ} \mathrm{C}\end{array}$ & Не вказано & $\begin{array}{c}\text { від } 0{ }^{\circ} \mathrm{C} \text { до } \\
30^{\circ} \mathrm{C}\end{array}$ & $\begin{array}{c}\text { від }-20{ }^{\circ} \mathrm{C} \text { до } 40 \\
{ }^{\circ} \mathrm{C}\end{array}$ & $\begin{array}{c}\text { у сухому } \\
\text { провітрюв } \\
\text { аному } \\
\text { приміщен } \\
\text { ні від } 0{ }^{\circ} \mathrm{C} \\
\text { до } 20^{\circ} \mathrm{C} \text { та } \\
\text { відностній } \\
\text { вологості } \\
\text { повітря не } \\
\text { більше } \\
75 \%\end{array}$ \\
\hline $\begin{array}{c}\text { Термін } \\
\text { придатності }\end{array}$ & $\begin{array}{l}5 \text { років } 3 \\
\text { дати } \\
\text { виготов- } \\
\text { лення }\end{array}$ & $11 / 2022$ & $\begin{array}{l}60 \text { місяців } \\
24 / 10 / 2022\end{array}$ & $\begin{array}{c}10 \text { років } 3 \text { дати } \\
\text { виготовлення }\end{array}$ & $\begin{array}{c}5 \text { років від } \\
\text { дати, що } \\
\text { вказана на } \\
\text { упаковці }\end{array}$ \\
\hline $\begin{array}{l}\text { Номер } \\
\text { партії }\end{array}$ & - & - & 111 & 011-14-N3 & $\begin{array}{r}\text { ПО53 } \\
\text { 13:00 } \\
\end{array}$ \\
\hline $\begin{array}{c}\text { Позначення } \\
\text { норматив- } \\
\text { ного } \\
\text { документа }\end{array}$ & $\begin{array}{c}\text { TУ У } \\
24.3- \\
23707000 \\
19- \\
001: 2005\end{array}$ & - & - & $\begin{array}{c}\text { ТУ 2383-001- } \\
92456191-2012\end{array}$ & $\begin{array}{l}\text { ТУ у } 24.5- \\
35008490- \\
006: 2011\end{array}$ \\
\hline
\end{tabular}


У зразку 2 (TM Silver) відсутня чітка інформація щодо умов зберігання. Однак зазначено, що продукт необхідно: «берегти від потрапляння прямих сонячних променів і нагрівання зверху до $50{ }^{\circ} \mathrm{C}$.

Варто відзначити, що у зразку 5 (TM Blyskavka) не зазначено інформацію щодо вмісту озоноруйнівних сполук.

Ознаки упакування зразків оцінювали у відповідності до [6]. Результати представлено у таблиці 5.

Таблиця 5

\section{Характеристика пакування фарб для оновлення кольору взуття різних} виробників

\begin{tabular}{|c|c|c|c|c|c|}
\hline \multirow{2}{*}{$\begin{array}{l}\text { Наймену- } \\
\text { вання } \\
\text { показника }\end{array}$} & \multicolumn{5}{|c|}{ Зразок / Торговельна марка } \\
\hline & $\begin{array}{c}\text { Зразок } 1 \text { / } \\
\text { Salton }\end{array}$ & $\begin{array}{c}\text { Зразок } 2 \text { / } \\
\text { Silver }\end{array}$ & $\begin{array}{c}\text { Зразок } 3 \text { / } \\
\text { Sitil }\end{array}$ & $\begin{array}{c}\text { Зразок 4 / } \\
\text { Twist }\end{array}$ & $\begin{array}{l}\text { Зразок } 5 \text { / } \\
\text { Blyskavka }\end{array}$ \\
\hline $\begin{array}{l}\text { Матеріал, } \\
\text { конструкція } \\
\text { ковпачка }\end{array}$ & $\begin{array}{c}\text { пластик } \\
\text { жовтого } \\
\text { кольору, } \\
\text { середньої } \\
\text { жорстокості, } \\
\text { пружний }\end{array}$ & $\begin{array}{c}\text { пластик } \\
\text { сірого } \\
\text { кольору, } \\
\text { середньої } \\
\text { жорстокості, } \\
\text { пружний. Два } \\
\text { види щіточок } \\
\text { із ПВХ }\end{array}$ & $\begin{array}{c}\text { пластик } \\
\text { чорного } \\
\text { кольору, } \\
\text { середньої } \\
\text { жорстокості, } \\
\text { пружний }\end{array}$ & $\begin{array}{c}\text { пластик } \\
\text { чорного } \\
\text { кольору, } \\
\text { середньої } \\
\text { жорстокості, } \\
\text { пружний }\end{array}$ & $\begin{array}{c}\text { пластик } \\
\text { чорного } \\
\text { кольору, } \\
\text { середньої } \\
\text { жорстокості, } \\
\text { пружний }\end{array}$ \\
\hline $\begin{array}{l}\text { Розпилю- } \\
\text { вальний } \\
\text { клапан }\end{array}$ & $\begin{array}{c}\text { тип «мама», } \\
\text { пластик } \\
\text { білого } \\
\text { кольору }\end{array}$ & $\begin{array}{c}\text { тип не } \\
\text { становлено, } \\
\text { пластик } \\
\text { чорного } \\
\text { кольору } \\
\end{array}$ & $\begin{array}{c}\text { тип «папа», } \\
\text { пластик } \\
\text { білого } \\
\text { кольору }\end{array}$ & $\begin{array}{c}\text { тип «папа», } \\
\text { пластик } \\
\text { помаранче- } \\
\text { вого кольору }\end{array}$ & $\begin{array}{c}\text { тип «папа», } \\
\text { пластик } \\
\text { білого } \\
\text { кольору }\end{array}$ \\
\hline $\begin{array}{l}\text { Видимі } \\
\text { дефекти } \\
\text { клапану }\end{array}$ & не виявлено & не виявлено & $\begin{array}{c}\text { клапан } \\
\text { закріплено } \\
\text { не по осі, що } \\
\text { призводить } \\
\text { до підтікання } \\
\text { фарби під } \\
\text { час } \\
\text { розпилення }\end{array}$ & не виявлено & не виявлено \\
\hline
\end{tabular}

Дослідженнями пакування встановлено, що у зразках 1, 4 та 5 видимих дефектів упакування не виявлено.

Розпилювальний клапан зразка 3 (TM Sitil) встановлено із порушенням конструкції, що призводить до підтікання фарби під час розпилення, а також до від’єднання клапану від балону.

У зразку 2 (TM Silver) полімерна плівка, із маркуванням відшарувалась від основи. Під нею виявлено нанесене маркування методом офсетного друку 
на жерсть, однак на інший продукт цієї ж торгової марки. Що свідчить про можливі фальсифікації з боку виробника щодо підміни продукту.

Результати дослідження показників якості наведено в таблиці 6.

Таблиця 6

Характеристика показників якості фарб для оновлення кольору взуття різних виробників

\begin{tabular}{|c|c|c|c|c|c|}
\hline \multirow{2}{*}{$\begin{array}{c}\text { Найменування } \\
\text { показника }\end{array}$} & \multicolumn{5}{|c|}{ Зразок / Торговельна марка } \\
\hline & $\begin{array}{l}\text { Зразок } 1 / \\
\text { Salton }\end{array}$ & $\begin{array}{c}\text { Зразок } 2 / \\
\text { Silver }\end{array}$ & $\begin{array}{c}\text { Зразок } 3 \text { / } \\
\text { Sitil }\end{array}$ & $\begin{array}{c}\text { Зразок 4 / } \\
\text { Twist }\end{array}$ & $\begin{array}{l}\text { Зразок } 5 \text { / } \\
\text { Blyskavka }\end{array}$ \\
\hline 1 & 2 & 3 & 4 & 5 & 6 \\
\hline Запах & інтенсивний & інтенсивний & інтенсивний & інтенсивний & інтенсивний \\
\hline $\begin{array}{l}\text { Швидкість } \\
\text { висихання, хв }\end{array}$ & $<15$ & $<20$ & $<60$ & $>180$ & $<180$ \\
\hline Покривність & $\begin{array}{c}\text { середня, } \\
\text { помітні шари } \\
\text { розпилення }\end{array}$ & $\begin{array}{c}\text { середня, } \\
\text { помітні } \\
\text { шари } \\
\text { розпилення }\end{array}$ & $\begin{array}{c}\text { висока, } \\
\text { рівномірне } \\
\text { покриття } \\
\text { без } \\
\text { розшару- } \\
\text { вань } \\
\end{array}$ & $\begin{array}{c}\text { висока, } \\
\text { рівномірне } \\
\text { покриття без } \\
\text { розшарувань }\end{array}$ & $\begin{array}{c}\text { низька, } \\
\text { видимі шари } \\
\text { розпилення }\end{array}$ \\
\hline $\begin{array}{l}\text { Насиченість } \\
\text { кольору }\end{array}$ & $\begin{array}{c}\text { середня, } \\
\text { колір має } \\
\text { сірий } \\
\text { відтінок }\end{array}$ & $\begin{array}{c}\text { середня, } \\
\text { колір має } \\
\text { сірий } \\
\text { відтінок }\end{array}$ & $\begin{array}{c}\text { середня, } \\
\text { колір має } \\
\text { сірий } \\
\text { відтінок }\end{array}$ & $\begin{array}{c}\text { висока, } \\
\text { насичений } \\
\text { рівномірний } \\
\text { яскраво } \\
\text { виражений } \\
\text { колір }\end{array}$ & $\begin{array}{c}\text { низька, } \\
\text { колір сірий, } \\
\text { не } \\
\text { відповідає } \\
\text { заявленому }\end{array}$ \\
\hline $\begin{array}{l}\text { Стійкість до } \\
\text { стирання }\end{array}$ & $\begin{array}{c}\text { висока, після } \\
\text { повного } \\
\text { висихання не } \\
\text { стирається і } \\
\text { не мажеться }\end{array}$ & $\begin{array}{c}\text { висока, } \\
\text { після } \\
\text { повного } \\
\text { висихання } \\
\text { не } \\
\text { стирається і } \\
\text { не мажеться }\end{array}$ & $\begin{array}{c}\text { середня, } \\
\text { після } \\
\text { повного } \\
\text { висихання } \\
\text { не } \\
\text { мажеться, } \\
\text { але } \\
\text { стирається }\end{array}$ & $\begin{array}{c}\text { середня, } \\
\text { після } \\
\text { повного } \\
\text { висихання не } \\
\text { мажеться, } \\
\text { але } \\
\text { стирається }\end{array}$ & $\begin{array}{c}\text { низька, після } \\
\text { повного } \\
\text { висихання } \\
\text { стирається і } \\
\text { мажеться }\end{array}$ \\
\hline Липкість & відсутня & відсутня & відсутня & $\begin{array}{c}\text { відчувається } \\
\text { незначна }\end{array}$ & відчувається \\
\hline $\begin{array}{l}\text { Водовідштовху- } \\
\text { вальний ефект }\end{array}$ & $\begin{array}{c}\text { краплі рідини } \\
\text { стікають без } \\
\text { затримки }\end{array}$ & $\begin{array}{c}\text { краплі } \\
\text { рідини } \\
\text { стікають без } \\
\text { затримки }\end{array}$ & $\begin{array}{c}\text { краплі } \\
\text { рідини } \\
\text { стікають без } \\
\text { затримки }\end{array}$ & $\begin{array}{c}\text { краплі } \\
\text { рідини } \\
\text { просочують } \\
\text { ворс }\end{array}$ & $\begin{array}{c}\text { краплі } \\
\text { рідини } \\
\text { помітно } \\
\text { просочують } \\
\text { ворс }\end{array}$ \\
\hline
\end{tabular}


Дослідженнями пакування встановлено, що у зразках 1, 4 та 5 видимих дефектів упакування не виявлено. Розпилювальний клапан зразка 3 (TM Sitil) встановлено із порушенням конструкції, що призводить до підтікання фарби під час розпилення, а також до від’єднання клапану від балону.

У зразку 2 (TM Silver) полімерна плівка, із маркуванням відшарувалась від основи. Під нею виявлено нанесене маркування методом офсетного друку на жерсть, однак на інший продукт цієї ж торгової марки. Що свідчить про можливі фальсифікації з боку виробника щодо підміни продукту.

Авторами було проведено розрахунок комплексного показника якості фарб для оновлення кольору взуття методом експертних оцінок, який містить аналіз найважливіших складових товару та порівняльну характеристику цих параметрів. Оцінка комплексного показника якості дозволяє в цілому охарактеризувати якість об'єкта або групу його властивостей. Експертна оцінка якості як складова товарознавчої оцінки передбачає послідовний аналіз простих і складних властивостей продукції та оцінювання ваги впливу кожної 3 них на якість продукції.

На першому етапі було проведено ранжування експертами обраних критеріїв, визначено їх вагомість, проведено обрання найбільш значущих та узгодженість думок експертів.

Так експертами обрано як найбільш вагомі показники якості фарб для взуття: насиченість кольору - X1; покривна здатність - X2; стійкість до стирання - X3; запах - X4; якість упакування, відсутність зовнішніх дефектів - Х5; відповідність та зрозумілість маркування - Х6; швидкість висихання X7; бренд (виробник) - Х8; водовідштовхувальні властивості - Х9; безпечність, екологічність - Х10. (табл. 7).

Таблиця 7

\section{Результати експертного ранжування показників якості фарб для взуття}

\begin{tabular}{|c|c|c|c|c|c|c|c|c|c|c|}
\hline \multirow{2}{*}{$\begin{array}{c}\text { Експер } \\
\text { ти }\end{array}$} & \multicolumn{10}{|c|}{ Оціночні критерії } \\
\cline { 2 - 13 } & $\mathrm{X}_{1}$ & $\mathrm{X}_{2}$ & $\mathrm{X}_{3}$ & $\mathrm{X}_{4}$ & $\mathrm{X}_{5}$ & $\mathrm{X}_{6}$ & $\mathrm{X}_{7}$ & $\mathrm{X}_{8}$ & $\mathrm{X}_{9}$ & $\mathrm{X}_{10}$ \\
\hline 1 & 2 & 4 & 1 & 3 & 10 & 9 & 7 & 8 & 6 & 5 \\
\hline 2 & 1 & 2 & 3 & 9 & 10 & 8 & 7 & 6 & 5 & 4 \\
\hline 3 & 3 & 2 & 1 & 4 & 6 & 7 & 8 & 9 & 10 & 5 \\
\hline 4 & 5 & 6 & 1 & 9 & 8 & 10 & 7 & 4 & 2 & 3 \\
\hline $\mathrm{S}$ & 11 & 14 & 6 & 25 & 34 & 34 & 29 & 27 & 23 & 17 \\
\hline $\mathrm{d}$ & -11 & -8 & -16 & 3 & 12 & 12 & 7 & 5 & 1 & -5 \\
\hline $\mathrm{d}^{2}$ & 121 & 64 & 256 & 9 & 144 & 144 & 49 & 25 & 1 & 25 \\
\hline $\mathrm{V}$ & 0,05 & 0,063 & 0,027 & 0,113 & 0,154 & 0,154 & 0,131 & 0,123 & 0,104 & 0,077 \\
\hline
\end{tabular}


Результати обчислень вказують на те, що найважливішими показниками споживних властивостей фарб для оновлення кольору взуття $\epsilon$ насиченість кольору - Х1; покривна здатність - Х2; стійкість до стирання - Х3.

Узгодженість думок експертів склала $\mathrm{Wg}=0,64$, що свідчить про достатню узгодженість.

Наступним проводилось ранжування кожного показника споживних властивостей для 5 обраних зразків фарб, де конкретним значенням показників якості продукції привласнювались ранги: чим вищий показник якості зразка, тим менше кількісне значення його рангу присвоювалось.

Зведені результати ранжування кожного показника споживних властивостей для 5 обраних фарб наведено в таблиці 8.

Таблиця 8

Сумарні ранги показників якості досліджуваних зразків фарб для оновлення кольору

\begin{tabular}{|c|c|c|c|c|c|}
\hline \multirow[b]{2}{*}{ Показник якості } & \multicolumn{5}{|c|}{ Сумарні ранги (Ki) показників якості фарб } \\
\hline & $\begin{array}{c}\text { Зразок } 1 \\
\left(\mathrm{y}_{1}\right)\end{array}$ & $\begin{array}{c}\text { Зразок } 2 \\
\left(\mathrm{y}_{2}\right)\end{array}$ & $\begin{array}{c}\text { Зразок } 3 \\
\left(\mathrm{y}_{3}\right)\end{array}$ & $\begin{array}{c}\text { Зразок } 4 \\
\left(\mathrm{Y}_{4}\right)\end{array}$ & $\begin{array}{c}\text { Зразок } 5 \\
\left(\mathrm{Y}_{5}\right)\end{array}$ \\
\hline Насиченість кольору $\left(\mathrm{X}_{1}\right)$ & 10 & 10 & 16 & 4 & 20 \\
\hline Покривна здатність $\left(\mathrm{X}_{2}\right)$ & 12 & 9 & 15 & 4 & 20 \\
\hline Стійкість до стирання $\left(\mathrm{X}_{3}\right)$ & 6 & 6 & 14 & 20 & 14 \\
\hline Запах $\left(\mathrm{X}_{4}\right)$ & 16 & 5 & 17 & 12 & 9 \\
\hline $\begin{array}{l}\text { Якість упакування, відсутність } \\
\text { зовнішніх дефектів }\left(\mathrm{X}_{5}\right)\end{array}$ & 4 & 17 & 11 & 14 & 14 \\
\hline $\begin{array}{l}\text { Відповідність та зрозумілість } \\
\text { маркування }\left(\mathrm{X}_{6}\right)\end{array}$ & 5 & 19 & 11 & 8 & 17 \\
\hline Швидкість висихання $\left(\mathrm{X}_{7}\right)$ & 4 & 8 & 12 & 20 & 16 \\
\hline Бренд (виробник) $\left(\mathrm{X}_{8}\right)$ & 7 & 10 & 12 & 14 & 17 \\
\hline $\begin{array}{l}\text { Водовідштовхувальні } \\
\text { властивості }\left(\mathrm{X}_{9}\right)\end{array}$ & 6 & 6 & 14 & 17 & 17 \\
\hline $\begin{array}{l}\text { Безпечність, екологічність } \\
\left(\mathrm{X}_{10}\right)\end{array}$ & 9 & 11 & 10 & 13 & 17 \\
\hline
\end{tabular}

На завершальному етапі досліджень проведено розрахунок комплексного показника якості фарб для оновлення кольору (табл.9).

3 розрахунку сумарного зваженого ранжування 5 зразків фарб для оновлення кольору взуття різних виробників найвищий комплексний показник якості у зразка 1 TM Salton (7,314), значно нижчі мають зразок 2 TM Silver $(11,087)$ та зразок 3 TM Sitil $(12,706)$ відповідно. Найгірший результат у фарби вітчизняного виробництва ТМ Blyskavka (зразок 5) - 15,693. 


\section{Таблиця 9}

Результати розрахунку комплексного показника якості зразків фарб для оновлення кольору взуття різних виробників

\begin{tabular}{|c|c|c|c|c|c|c|c|c|c|c|c|}
\hline \multirow{2}{*}{$\begin{array}{c}\text { Показ- } \\
\text { ник } \\
\text { якості }\end{array}$} & \multirow{2}{*}{$\begin{array}{c}\text { Коефіці- } \\
\epsilon \text { т } \\
\text { вагомості } \\
\alpha\end{array}$} & \multicolumn{5}{|c|}{ Сумарні ранги $-K i$} & \multicolumn{5}{|c|}{ Показник якості за і-ю ознакою $(K i \times \alpha)$} \\
\hline & & $\mathrm{y}_{1}$ & $\mathrm{y}_{2}$ & $\mathrm{y}_{3}$ & $\mathrm{y}_{4}$ & $\mathrm{y}_{5}$ & $\alpha \times K_{1}$ & $\alpha \times K_{2}$ & $\alpha \times K_{3}$ & $\alpha \times K_{4}$ & $\alpha \times K_{5}$ \\
\hline 1 & 2 & 3 & 4 & 5 & 6 & 7 & 8 & 9 & 10 & 11 & 12 \\
\hline $\mathrm{X}_{1}$ & 0,05 & 10 & 10 & 16 & 4 & 20 & 0,5 & 0,5 & 0,8 & 0,2 & 1,0 \\
\hline $\mathrm{X}_{2}$ & 0,063 & 12 & 9 & 15 & 4 & 20 & 0,756 & 0,567 & 0,945 & 0,252 & 1,26 \\
\hline$X_{3}$ & 0,027 & 6 & 6 & 14 & 20 & 14 & 0,162 & 0,162 & 0,378 & 0,54 & 0,378 \\
\hline $\mathrm{X}_{4}$ & 0,113 & 16 & 5 & 17 & 12 & 9 & 1,808 & 0,565 & 1,921 & 1,356 & 1,017 \\
\hline $\mathrm{X}_{5}$ & 0,154 & 4 & 17 & 11 & 14 & 14 & 0,616 & 2,618 & 1,694 & 2,156 & 2,156 \\
\hline $\mathrm{X}_{6}$ & 0,154 & 5 & 19 & 11 & 8 & 17 & 0,77 & 2,926 & 1,694 & 1,232 & 2,618 \\
\hline $\mathrm{X}_{7}$ & 0,131 & 4 & 8 & 12 & 20 & 16 & 0,524 & 1,048 & 1,572 & 2,62 & 2,096 \\
\hline $\mathrm{X}_{8}$ & 0,123 & 7 & 10 & 12 & 14 & 17 & 0,861 & 1,23 & 1,476 & 1,722 & 2,091 \\
\hline $\mathrm{X}_{9}$ & 0,104 & 6 & 6 & 14 & 17 & 17 & 0,624 & 0,624 & 1,456 & 1,768 & 1,768 \\
\hline $\mathrm{X}_{10}$ & 0,077 & 9 & 11 & 10 & 13 & 17 & 0,693 & 0,847 & 0,77 & 1,001 & 1,309 \\
\hline \multirow{2}{*}{\multicolumn{7}{|c|}{ Комплексний показник якості }} & & & & & \\
\hline & & & & & & & 7,31 & 11,09 & 12,71 & 12,85 & 15,69 \\
\hline
\end{tabular}

\section{Висновки та перспективи подальших досліджень.}

1. За результатами проведеного аналізу стану технічної документації на засоби по догляду за взуттям можна стверджувати, що в даній галузі чинними $\epsilon$ технічні умови, які відповідають вимогам часу, $\epsilon$ прозорими та чітко встановлюють показники якості та безпечності. Проте це відноситься лише до вітчизняної продукції. Відсутні гармонізовані нормативні документи для оцінювання імпортної продукції.

2. Таким чином, найбільш повне та інформативне маркування є у зразках 1 (TM Salton) та 4 (TM Twist). Найбільше порушень та невідповідностей зафіксовано у зразка 2 (TM Silver).

3. Встановлено, що у зразках 1,4 та 5 видимі дефекти упакування відсутні. У зразку 3 (TM Sitil) виявлено порушення конструкції розпилювального клапану, що призводить до підтікання фарби під час розпилення та від’єднання клапану від балону. 
У зразку 2 (TM Silver) зафіксовано відшарування полімерної плівки, із маркуванням від балону. Під плівкою виявлено маркування нанесене методом офсетного друку на жерсть. Однак вказане маркування на інший продукт цієї ж торгової марки, що свідчить про можливі фальсифікації з боку виробника щодо підміни продукту.

4. За результатами досліджень функціональних показників, встановлено, що у всіх зразках присутній інтенсивний технічний запах, характерний для товарів даної групи. За показниками швидкості висихання, стійкості до стирання та водовідштовхувальної дії найкращі результати виявлено у зразків TM Salton та Silver (зразки 1 і 2); покривність та насиченість кольору - у фарби ТM Twist (зразок 4).

5. На завершальному етапі досліджень проведено розрахунок комплексного показника якості фарб для оновлення кольору. 3 розрахунку сумарного зваженого ранжування 5 зразків фарб для оновлення кольору взуття різних виробників найвищі комплексні показники якості мають зразки 1, 2, 3, TM Salton (7,314), TM Silver (11,087), TM Sitil $(12,706)$ відповідно.

\section{Список використаних джерел}

1. Офіційний сайт торгової марки SALTON URL: https://salton.ua/

2. ДСТУ ISO 3668:2019. Фарби та лаки. Візуальне порівняння кольору фарб (ISO 3668:2017, IDT) URL: http://online.budstandart.com/ua/catalog/doc-page.html?id_doc=82756

3. ДСТУ ISO 28199-2:2015 Фарби та лаки. Оцінювання властивостей систем покриття, пов'язаних із процесом нанесення. Частина 2. Стабільність кольору, технологічна покривність, повторне розчинення, поглинання надлишку за перерозпилення, змочування, текстура поверхні та нерівномірне фарбування (ISO 28199-2:2009, IDT) URL: http://online.budstandart.com/ua/component/virtuemart/3_3/iinstytuty_6115/dp_\%C2\%ABukrayi ns\%20kyi_nau_61041/28199-2-2015+82539-detail.html?Itemid=0

4. ДСТУ ISO 2812-4:2015 Фарби та лаки. Визначення стійкості до впливу рідини. Частина 4. Краплинні методи (ISO 2812-4:2007, IDT) URL: http://online.budstandart.com/ua/catalog/doc-page.html?id_doc=77847

5. Державний класифікатор продукції та послуг ДК 016:2010 URL: https://zakon.rada.gov.ua/rada/show/v457a609 10

6. ТУ 61598486 «Засоби рідкі по догляду за взуттям та виробами зі шкіри» URL: https://www.twirpx.com/file/2292018/

7. ГСТУ 30502004 Продукція хімічна (Товари побутової хімії). Маркування URL: http://online.budstandart.com/ru/catalog/doc-page?id_doc $=65667$

8. ГСТУ 30512004 Продукція хімічна (Товари побутової хімії). Пакування URL: http://online.budstandart.com/ru/catalog/doc-page?id_doc=65667 
9. СОУ МПП 71.100 077:2004 Продукция химическая (товары бытовой химии). Правила приемки. Изменение №1 URL: http:/online.budstandart.com/ua/catalog/docpage.html?id_doc=65669

10. СОУ МПП 71.100 078:2004 Продукция химическая (товары бытовой химии). Транспортировка и хранение URL: http://online.budstandart.com/ua/catalog/docpage.html?id_doc=66506

\section{References}

1. Ofitsiynyy sayt torhovoyi marky SALTON URL: https://salton.ua/

2. Farby ta laky. Vizual'ne porivnyannya kol'oru farb (ISO 3668:2017, IDT) DSTU ISO 3668:2019 (2019) URL: http://online.budstandart.com/ua/catalog/doc-page.html?id_doc=82756

3. Farby ta laky. Otsinyuvannya vlastyvostey system pokryttya, pov"yazanykh iz protsesom nanesennya. Chastyna 2. Stabil'nist' kol'oru, tekhnolohichna pokryvnist', povtorne rozchynennya, pohlynannya nadlyshku za pererozpylennya, zmochuvannya, tekstura poverkhni ta nerivnomirne farbuvannya (ISO 28199-2:2009, IDT) DSTU ISO 28199-2:2015 (2015) URL: http://online.budstandart.com/ua/component/virtuemart/3_3/iinstytuty_6115/dp_\%C2\%ABukrayi ns\%20kyi_nau_61041/28199-2-2015+82539-detail.html?Itemid=0

4. Farby ta laky. Vyznachennya stiykosti do vplyvu ridyny. Chastyna 4. Kraplynni metody (ISO 2812-4:2007, IDT) DSTU ISO 2812-4:2015 (2015) URL: http://online.budstandart.com/ua/catalog/doc-page.html?id_doc $=77847$

5. Derzhavnyy klasyfikator produktsiyi ta posluh DK 016:2010 URL: https://zakon.rada.gov.ua/rada/show/v457a609 10

6. Zasoby ridki po dohlyadu za vzuttyam ta vyrobamy zi shkiry TU 61598486 (1986) URL: https://www.twirpx.com/file/2292018/

7. Produktsiya khimichna (Tovary pobutovoyi khimiyi). Markuvannya HSTU 30502004 (2004) URL: http://online.budstandart.com/ru/catalog/doc-page?id_doc=65667

8. Produktsiya khimichna (Tovary pobutovoyi khimiyi). Pakuvannya HSTU 30512004 (2004) URL: http://online.budstandart.com/ru/catalog/doc-page?id_doc=65667

9. Produktsyya khymycheskaya (tovary bytovoy khymyy). Pravyla pryemky. Yzmenenye №1 SOU MPP 71.100 077:2004 (2004) URL: http://online.budstandart.com/ua/catalog/docpage.html?id_doc=65669

10. Produktsyya khymycheskaya (tovary bytovoy khymyy). Transportyrovka y khranenye SOU MPP 71.100 078:2004 (2004) URL: http://online.budstandart.com/ua/catalog/docpage.html?id_doc $=66506$

Цель. Определение классификационных показателей средств ухода за обувью и проведение товароведческой оценки спреев для обновления извета.

Методика. Исследования проводились путем применения общенаучных методов, сравнительного и системного анализа, а также применены объективные и субъективные методы:: диагностические и информационно-аналитические (математические, экспертные, логические и т.д.).

Результаты. В статье представлен анализ базовых классификационных показателей средств ухода за обувью. Проведен анализ действующих требований к 
качеству, маркировке и упаковке объекта исследований. Установлено, что в Украине нет ни одного специализированного ГОСТ на средства ухода за обувью. Почти все производители, представленные на рынке, разрабатывают собственные технические условия, или пользуются причастными нормативными документами.

Осуществлена товароведческая оченка красок для обновления ивета отечественных и иностранных производителей, представленных на отечественном рынке. Предложенный авторами алгоритм товароведческой оценки предусматривает этапь: исследование соответствия маркировки; проверку состояния и качества упаковки; оценку показателей функииональных свойств; расчет комплексного показателя качества методом экспертных оценок. Такая схема позволяет повысить эффективность формирования ассортимента в розничных сетях.

Научная новизна. Впервые предложена классификация средств по уходу за обувью по базовым показателям; усовершенствован алгоритм товароведческой оценки средств ухода за обувью, в частности красок для обновления цвета.

Практическая значимость. Полученные результаты оценки качества спреев для обуви и предложенная автором классификация могут использоваться специалистами при формировании ассортимента средств по уходу за обувью в торговых сетях Украиныл.

Ключевые слова: средства по уходу за обувью, спреи для обновления иявета, товароведческая оченка, классификащия, ассортимент.

Goal. Determination of classification indicators for shoe care products and merchandising assessment of sprays for color renewal.

Methodology. The studies were carried out by applying general scientific methods, comparative and system analysis, and objective and subjective methods were applied: diagnostic and information-analytical (mathematical, expert, logical, etc.).

Results. The article presents an analysis of the basic classification indicators of shoe care products. The analysis of the current requirements for the quality, labeling and packaging of the object of study. It has been established that in Ukraine there is not a single specialized GOST for shoe care products. Almost all manufacturers on the market develop their own technical conditions, or use the involved regulatory documents.

A merchandising assessment of paints was carried out to update the colors of domestic and foreign manufacturers represented on the domestic market. The merchandising assessment algorithm proposed by the authors includes the following stages: investigation of labeling compliance; checking the condition and quality of packaging; assessment of indicators of functional properties; calculation of a comprehensive quality indicator by expert estimates. Such a scheme makes it possible to increase the efficiency of assortment formation in retail chains.

Scientific novelty. For the first time, a classification of shoe care products by basic indicators is proposed; The algorithm for merchandising assessment of shoe care products, in particular paints for updating colors, has been improved.

Practical significance. The results of assessing the quality of shoe sprays and the classification proposed by the author can be used by specialists in the formation of an assortment of shoe care products in retail chains of Ukraine.

Keywords: shoe care products, color renewal sprays, merchandising assessment, classification, assortment.

Стаття рекомендована до публікачії доктором технічних наук професором Вінницького торговельно-економічного інституту КНТЕУ Бондаренко В.М. Стаття надійшла в редакиію 28.11.2019 p. 